\title{
Transmedial Transduction in the Spider-Verse
}

\section{José Agustín Donoso Munita ${ }^{1}$ Mariano Alejandro Penafiel Durruty²}

Recibido: 2016-09-09

Enviado a pares: 2016-09-12
Aprobado por pares: 2017-02-17

Aceptado: 2017-03-16

DOI: 10.5294/pacla.2017.20.3.8

\section{Para citar este artículo / to reference this article / para citar este artigo}

Donoso Munita, J.A. y Penafiel Durruty, M.A. (2017). Transmedial transduction in the spider-verse. Palabra Clave, 20(3), 763-787. DOI: 10.5294/pacla.2017.20.3.8

\section{Abstract}

Since Spider-Man was born from the hands of Stan Lee and Steve Ditko in 1962, thousands of versions of the arachnid have been created. Among them, two call the attention of this investigation: Spider-Man India and Supaidaman (1978), from Japan. By using a comparative study of the hero's journey between these two and the original Spider-Man, this study attempts to understand transduction, made to generate cultural proximity with the countries where the adaptations were made. This study also seeks to understand how all the versions of the arachnid were united to generate one integrated and coherent universe that has multiple worlds, by creating a retroactive linkage, which was launched by Slott et al. in 2014. By looking into the rules set by fiction itself, this investigation aims to see if the two Spider-Men studied are just adaptations of the original one, or if they are part of a Transmedial Universe.

\section{Keywords}

Adaptation; cultural proximity; retroactive linkage; Spider-Man; transduction; transmedia; multiverse; transcultural (Source: Unesco Thesaurus).

1 Universidad de Los Andes. Chile.jdonoso@uandes.cl

2 Universidad de Los Andes. Chile. mapenafiel@miuandes.cl 


\section{Transducción transmedial en el multiverso araña}

\section{Resumen}

Desde el nacimiento del Hombre Araña a manos de Stan Lee y Steve Ditko en 1962, se han creado miles de versiones del arácnido. Entre estos, dos llaman la atención de esta investigación: Spider-Man India y el Supaidaman (1978) japonés. A partir de un estudio comparativo del monomito entre estas dos versiones y el Hombre Araña original, el presente estudio busca comprender la transducción, realizada para generar una proximidad cultural con los países en donde se realizaron las adaptaciones. Este estudio también busca entender cómo se unieron todas las versiones del arácnido para generar un universo integrado y coherente formado por múltiples mundos, mediante la creación de un Enlace Retroactivo, y que fue lanzado en el año 2014. Al investigar las reglas establecidas por la misma ficción, la presente investigación tiene como objetivo determinar si los dos Hombre Araña estudiados son solo adaptaciones del original, o si forman parte de un Universo Transmedial.

\section{Palabras clave}

Adaptación, proximidad cultural, enlace retroactivo, Hombre-Araña, transducción, transmedia, multiverso, transcultural (Fuente: Tesauro de la Unesco). 


\section{Transdução transmídia no multiverso aranha}

\section{Resumo}

Desde a concepção do Homem Aranha por Stan Lee e Steve Ditko em 1962, milhares de versões do aracnídeo foram criadas, duas das quais chamam a atenção desta investigação: Spider-Man India e o Supaidaman (1978) japonês. Usando um estudo comparativo do monomito entre essas duas versões e o Homem Aranha original, este estudo procura compreender a transdução, realizada para gerar proximidade cultural com os países onde foram feitas as adaptações. Este estudo procura também entender como todas as versões do aracnídeo se uniram para gerar um universo integrado e coerente formado por vários mundos, mediante a criação de uma Ligação Retroativa, e que foi lançado em 2014. Examinando as regras estabelecidas pela própria ficção, esta pesquisa procura ver se os dois Homem Aranha estudados são apenas adaptações do original, ou se são parte de um universo transmídia.

\section{Palavras-chave}

Adaptação; proximidade cultural; ligação retroativa; Homem Aranha; transdução; transmídia; multiverso; transcultural (Fonte: Tesauro da Unesco). 


\section{Introduction}

On August 6, 2014, Marvel Comics published Superior Spider-Man \#32. In said series, one of the comic's classic villains, Doctor Otto Octavius-commonly known as Octopus - is an alternate version of Spider-Man, given that he occupies the body of Peter Parker. And in this particular edition, Superior Spider-Man begins a journey through many dimensions, showing us other versions of Spider-Man, among which some stand out, like the fusion between Spider-Man and Iron-Man, Spider-Man Noir, and even a Spider-Monkey (Slott et al., 2014).

With this journey, the Spider-Verse series began. In it, Marvel aspired to unite all the different Spider-Men in a great adventure against a common enemy (Slott et al., 2014).

This intent of showing all the existing Spider-Men in a single series presents the opportunity to investigate some versions of the arachnid that were born from a transduction (Uribe-Jongbloed \& Espinosa-Medina, 2014). The present investigation focuses particularly on two variations of the hero: Spider-Man India, known as Pavitr Prabhakar (Kang et al., 2005a) from Earth 50101, and Takuya Yamashiro, the Japanese Spider-Man, Supaidaman (Saeki \& Uehara, 1978), from Earth 51778.

These two were chosen because they were the only versions with the following characteristics: 1) They are Spider-Man stories set in countries different from the original, which makes them the product of a transduction; 2 ) they were written in their own countries, which means they are interpretations of their own cultures instead of visions that other cultures might have of them; 3 ) they are stories that originate prior to the Spider-Verse, which ensures that the transduction effort was made to bring the arachnid to the new cultural reality and not as a means to integrate this new cultural reality with the arachnids fictitious universe; and 4) you can find out the origin of the heroes in both stories, which allows us to establish more points of comparison.

Through the analysis of both works and their comparison with the original Spider-Man (Lee \& Ditko, 1962), this investigation will attempt 
to ascertain the transduction process carried out in both products, focusing especially on the elements that are added to achieve a better cultural approximation (Straubhaar, 1991). Besides, studying these versions of the arachnid and their origin stories, we aim to see if they are part of a coherent fictitious universe (Wolf, 2012) along with the original Spider-Man. If there is such a coherence, these transductions would be part of a transmedia universe (Jenkins, 2003), and not only iterative adaptations.

In synthesis, along with finding out if the transduction process is present in both Spider-Men, this investigation seeks to ascertain if they are just adaptations of the original, or if they expand their fictitious universe, making them part of a transmedia universe (Jenkins, 2009).

\section{Methodology}

To gain a better understanding of the transduction processes that generated both Spider-Men, this work will compare their origin stories with the original from 1962. This comparison will be done based on the Hero's Journey (Campbell, 1949), putting special emphasis on the adaptation of Christopher Vogler's (1998) model.

\section{Transduction, Transcreation and Hybridity}

The analysis will allow a comparison between the changes made in both adaptations, paying special attention to the plot and the cultural elements. The latter, bearing in mind that, at the time of creating Pavitr Prabhakar, Saharad Devarajan, president and CEO of the publishing house that released the Indian hero's first edition (Gotham Entertainment Group), defined the process that they carried out as Transcreation as " [...] where we actually reinvent the origin of a character so that he is an Indian boy growing up in Mumbai and dealing with local problems and challenges" (Kang et al., 2005a, p. 32).

Henry Jenkins (2006) studied the Indian Spider-Man phenomenon and categorized it as Corporate Hybridity:

Hybridity occurs when one cultural space-in this case, a national media industry-absorbs and transforms elements from another; a hy- 
brid work thus exists betwixt and between two cultural traditions while providing a path that can be explored from both directions. (p. 112)

The process of transcreation or Hybridity is further explored by Enrique Uribe-Jongbloed and Hernán David Espinosa-Medina (2014), who included it in what they called transduction. They support their definition of hibridity on Néstor García Canclini (2000), who defines it as an effect of the constant exchange of cultural products, where there are processes of mix, adaptations, modifications, and accommodations of different cultural praxis and texts.

Based on Georgette Wang and Emilie Yueh-yu Yeh (2005), Uribe-Jongbloed and Espinosa-Medina describe the transduction process as one of deculturalization, until a product composed of universals is attained, and then said product is re-culturalized to localize it (Uribe-Jongbloed \& Espinosa-Medina, 2014).

In simpler words, what would be done in this case is to remove all the elements of the product that might clash with the target culture, and then those blank spaces are filled with local elements from said target culture.

What this process achieves is a cultural approximation (Straubhaar, 1991). In his theory, Straubhaar says that, to some extent, the audience's preferences define how much a product can be changed when it goes from one market to another.

Cultural approximation has an important foundation in language, but there are also other levels that allow the generation of proximity, which are cultural elements, such as clothing, gestures, traditions, religion, etc. (La Pastina \& Straubhaar, 2005).

The transduction exercise is done by trying to achieve the highest cultural proximity between the product and the target market.

All the aforementioned authors agree in pointing out that this process of bringing in international content and relocating it in a national context arises as a response to globalization and the exchange of cultural products. 
The product that is created out of this process can be considered an adaptation or, in some cases, as part of a transmedia universe. To comprehend this, it is necessary to understand the dispute there is surrounding both of these concepts.

\section{Transmedia and Adaptation}

According to Henry Jenkins (2006), a transmedial narrative is that which takes part through multiple media platforms, where each new text makes a different and valuable contribution to the whole.

In the author's opinion, adaptations would not be part of transmedia- or at least not all would be-because they add nothing new to a fictitious universe, and instead he considers them redundant. Jenkins (2009) places special emphasis in expansion as a decisive factor in transmedial narrative, whereas, from his point of view, adaptation only moves content from one platform to another without expanding it.

Carlos Alberto Scolari (2012, 2013) raises an opposing voice, and instead presents the option that all adaptations are a particular kind of transmedia, to a point that, for him, even the most linear adaptation would include a new vision that deserves to be catalogued as an expansion and that constitutes a new access point to a shared fictitious world.

Scolari (2014) takes into account the four basic operations of rhetoric (i.e. addition, compression, transposition and permutation) and denominates them as transmedia strategy. It is precisely because of this that he considers adaptation as a part of transmediality. Actually, a transmedial operation of compression might be the adaptation of a literary work into a cinematographic work, in which probably many elements of the character's interior worlds would be omitted.

In line with this, Marta Frago (2005) states that, in the process of adapting to different platforms, changes are unavoidable, which would make the adaptation not redundant. The changes generated between an original work and its adaptation to another platform are produced in the understanding of a textual transference. Thus, in the case of the adaptation of a 
written work to television or cinema, changes are made because the written language is of a symbolic nature, whilst the visual is of an iconic nature. Frago (2005) will go beyond and say that the changes made are inevitable, not just due to the textual transference to another language, but because there is intervention along the process by individuals with different personalities and socio-historical situation from the literary author.

This would make it possible that, even if an adaptation was made within the same platform - what we would commonly call a remake - , modification would be inevitable. In this context, it seems worthy of consideration to argue in favor of Scolari's point because, no matter what, the new adapted release would inevitably have new elements that would somehow modify the first narrative universe.

In a similar sense, Christy Dena (2009) defies the positions that point to adaptations as something that is automatically redundant. For her, adaptation is a process in which "an adapter (whether a different person than the original creator or the same person) makes semiotically meaningful decisions" (p. 152).

In the end, we are in a position to say that an adaptation within the same platform inevitably implies changes, fruit of the decisions made by the adapter or by the contexts and, if it happens in different platforms, the personal specificity of that new platform is added to those variations.

On this last point, Dena relies on Espen Aarseth to graph the transferences that happened from one platform to another, as seen in Table 1.

\section{Table 1. Cross-media transference}

\begin{tabular}{|c|c|c|c|c|}
\hline Element & Ride to movie & Book to movie & Movie to game & Game to movie \\
\hline Storyline & No & Ok & Not really & No \\
\hline Events & Hardly & Ok & Hardly & Ok \\
\hline Universe & Ok & Ok & Ok & Ok \\
\hline Characters & No & Ok & Partly & Expanded \\
\hline
\end{tabular}

Source: Aarseth, as cited in Dena (2009, p. 171). 
When looking at Aarseth's table, we can see that, regardless of the kind of adaptation, the only thing that remains unchanged is the universe. Nonetheless, in the transduction process, when a story is brought from one context to another, what is being changed is, precisely, its world.

Marie-Laure Ryan (2008) includes this process in the concept of transfictionality, which refers to texts whose worlds are, at once, different in some respects while similar in others. This means that there are logical discrepancies between both worlds - they do not have continuity: "The worlds projected by the two texts must be distinct, but related to each other” (Ryan, 2008, p. 389).

Ryan follows Lubomir Dolezel's concept of postmodern rewriting. In this case, the texts have worlds that are related, and the nature of these relationships can be that of transposition, expansion and displacement. According to Dolezel (as cited in Ryan, 2008), the transposition maintains the design and main story, but locates the tale in a different space and/or time. The expansion extends the protoworld by filling in the holes and building a prior or posterior story. Finally, the displacement (or modification, as Ryan prefers to refer to it), builds different versions of the protoworld, redesigning its structure and reinventing its history (Dolezel as cited in Ryan, 2008).

Up to this point we could say that when a story breaks continuity it should not be considered as part of the transmedia concept, but rather as the result of a transfictional or transductional effort. But, is it possible to have transfictional or transductional works that are part of the transmedia universe of the original work?

This seems to be the case in the Marvel Multiverse and, in particular, in the Spider-Verse, where a posterior work is created that expands the universe with content that fills certain voids.

\section{Imaginary Worlds and the Marvel Multiverse}

Jenkins (2006) explains the importance of the construction of worlds in transmedia with a phrase that, apparently, an experienced writer told him: 
When I first started, you would pitch a story because without a good story, you didn't have a film. Later, once sequels started to take off, you pitched a character because a good character could support multiple stories. And now you pitch a world because a world can support multiple characters and multiple stories across multiple media. (p. 114)

The imaginary worlds can be huge, containing hundreds of hours of material in different platforms. MarkJ. P. Wolf (2012) explains that the enormity of these worlds is what makes their content capable of being shown across different windows.

In his study, Wolf (2012) lists the different imaginary worlds according to the distance they have relative to the real world. It begins with autobiographical works (that always have some level of construction), going across different levels_-amongst which he includes what he calls overlaid worlds - all the way to creations that defy what is known in our world.

Marvel's main universe would be a clear example of an overlaid world, where "fictional elements are overlaid onto a real location, but without separating a secondary world from the primary world" (Wolf, 2012, p. 27).

But, in this comic book publishing house there is more than one world, which eventually took them to numerating the different realities. The first numbering of worlds in Marvel is attributed to The Daredevils \# 7 (Moore et al., 1983). In this case, the writer, Alan Moore, decided that the universe in which the events of this comic book usually took place would be Earth 616 (McMillan, 2014). The numeration for this main Earth as 616, as revealed by Moore's Daugther, Leah, was entirely random, chosen because the author saw that no one had used high numbers to refer to other versions of the Earth (Christiansen, 2007).

Since then, Marvel has played around with the multiplicity of universes in different series, giving each new universe a new number. The Marvel multiverses are potentially infinite, giving creators space to rethink the existing series. All of this encapsulated under one concept: " [...] the term 'multiverse' is sometimes used, which describes the overall structure result- 
ing from the connection of two or more universes that, though connected, still remain distinct and separate" (Wolf, 2012, p. 216).

In the case of Spider-Man, this investigation has found as a first account of a journey by the hero through multiple universes, or dimensions, the final episodes of the last season of the animated series known as Spider-Man TAS (Lee \& Richardson, 1998).

In both examples we can find multiple parallel universes that interact. To explain said interaction, Wolf relies on the concepts of crossover and retroactive linkages. Crossovers would be objects or beings that appear in two or more universes, and retroactive linkages are the connections that are produced between worlds that were conceived separately and were not meant to be connected originally.

The examples of crossovers in comic books are many, and the case of the Spider-Verse, to which the present investigation is committed, is a retroactive linkages. When these are made seriously, they open the possibility to consolidate the author's efforts towards a world much larger than originally intended. However, Wolf (2012) recommends undertaking these efforts carefully:

[...] retroactive linkages can alter the context and canonicity of a work, and change how an audience sees a particular world and the overarching narratives taking place within it; so it must be done carefully, if it is to be done at all. (p. 219)

In a nutshell, retroactive linkages is a new work that must be done with enough care so as to be able to connect and give new sense to older works and, at the same time, allow both universes to remain apart, respecting the diversity of the audiences that might be reached by the works.

In the following lines, this investigation will analyze three storylines that belong to the Spider-Verse, a retroactive linkages from 2014 created to unify all the existing Spider-Men up to that point and also giving the opportunity to create new ones. The storylines to be analyzed are, as mentioned 
beforehand, the original (Earth 616), the Indian (Earth 50101), and the Japanese (Earth 51778).

\section{The Hero's Journey of Peter Parker from Earth 616}

On August 10, 1962, Spider-Man first saw the light of day from the hand of creators Stan Lee, the writer, and Steve Ditko, the artist. The hero had his origin story told on number 15 of The Amazing Fantasy in 1962.

In his ordinary world (Vogler, 1998), there is a youth who is weak and socially rejected by his high school classmates (Lee \& Ditko, 1962). Nonetheless, in this first illustration, you can already see that Peter is destined for a heroic future. Behind him, his shadow is projected as a strong man, surrounded by a cobweb beneath a giant spider. This is what this investigation calls a pre-call to adventure, given the innuendo that is made of Peter's destiny.

The actual call to adventure (Vogler, 1998) only reaches this kid once he visits a science fair where radioactive experiments are conducted.

But as the experiment begins, no one notices a tiny spider, descending from the ceiling on an almost invisible strand of web... A spider whom fate has given a starring, if brief, role to play in the drama we call life! Accidentally absorbing a fantastic amount of radioactivity, the dying insect, in sudden shock bites the nearest living thing, at the split second before life ebbs from its radioactive body! (Lee \& Ditko, 1962, p. 3).

That living thing happened to be Peter Parker, who then acquires superhuman strength, the skills of a spider, and his famous spider sense.

The refusal to the call (Vogler, 1998) happens when Peter lets a thief escape (Lee \& Ditko, 1962).

The meeting with the mentor, ordeal, and reward are stages that happen in a mixed-up order, different from the outline proposed by Vogler (1998). His mentor is his uncle, from whom he learns the biggest lesson of his life. 
His wisdom — or reward — will only be attained after his uncle dies and Peter understands his responsibility in the events. This is because the criminal that he let escape from the police is the same one who killed his uncle.

Closely knit to the previous stages, the crossing of the threshold, the approach to the deepest cavern, the road back, the resurrection, and the return with the elixir (Vogler, 1998) happen in very few moments due to Spider-Man's first adventure being short.

These stages continue out of order; when Peter decides he will find and punish his uncle's murderer, he reaches the stage called the crossing. The approach is brief, when Peter sees that the thief is alone and prepares to surprise him. Parker wants to take revenge in his own hands, until he realizes that it is the same thief he let escape and, thus, his uncle's death is his responsibility. After this discovery, he decides to deliver him to justice, somehow re-establishing balance to his life. In compensating the death of his uncle by catching the perpetrator, it can be said that Peter goes through the resurrection that will ultimately and definitively transform him into Spider-Man. The road back is very clear in the last image: Walking towards the horizon, Peter already is Spider-Man and his elixir is the phrase the narrator says and that summarizes his most important lesson: "with great power there must also come—great responsibility!" (Lee \& Ditko, 1962, p. 11).

From this point on, he will have great allies, enemies and tests (Vogler, 1998). His most renown enemies are the Green Goblin, Otto Octavius, Lizard, and Sandman, amongst others that were presented through the years in different comic books, television shows, and movies.

\section{The Hero's Journey of Pavitr Prabhakar from Earth 50101}

On November 17, 2004, the young Indian Pavitr Prabhakar had the opportunity to fulfill a dream that thousands of youths in the world have had when he became Spider-Man. 
In this case, the comic book begins with the pre-call to adventure. An entire page shows the image of a Yogui master amidst flames in Pavitr's old town. This time, the image of the spider takes on a central role (it is on the Yogui's forehead and projected over the palm of his open hand).

Prabhakar awakes from this dream into his ordinary world. In this case, he is an orphan living with his uncle Bhim and aunt Maya (just as Peter Parker who, as an orphan, lived with his uncle Ben and aunt May). And, just as in the original comic book, the protagonist suffers from being rejected by his peers: "Look girls, it's the first I.B.C.D_-Indian Born Confused Desi!" (Kang et al., 2005a, p. 3). They laugh at him for being from a different social condition and because he wears a dhoti, which is a one-piece traditionalist parachute pants made from cotton.

Being a storyline set in India, mysticism plays a fundamental role. In this case, the call to adventure comes from the apparition of the Yogui master to Pavitr when he's running away from some classmates that want to beat him up (Kang et al., 2005a).

Obtaining his powers - consisting on superhuman strength, the skills of a spider, and spider sense - causes the young man to become excited and start swinging between the buildings of Mumbai, imagining what he'll do with them. When he sees a woman being robbed, his reaction is practically identical to that of his North American counterpart, a refusal to the call (Kang et al., 2005a).

In this storyline, Prabhakar has two mentors: One was already mentioned - the Yogui master who gives him his powers as a reward — and the other is his uncle Bhim, who rewards him with the same gift that the original Spider-Man received at the end of his first adventure. In this case, Prabhakar also disregards his uncle's words, only understanding them at the end of the story. And what his uncle tells him is a trustworthy reflection of the original comic book: "with great power comes great responsibility" (Kang et al., 2005a, p. 8). 
It is important to point out that this phrase is attributed directly to uncle Bhim (and not to the narrator, like in the original comic book). This might be due to the fact that this comic book was released after the first Spider-Man movie, directed by Sam Raimi (2002), where the famous phrase is attributed to uncle Ben.

Just as with the Spider-Man from Earth 616, once he finds out his uncle has died, Pavitr crosses the threshold and seeks to exact vengeance. When he finds his uncle's murderers, he is about to kill them but realizes that it was his indifference that actually killed Bhim. From that point on, he will be a hero.

In this case, as mentioned before, the first Spider-Man adventure consists of four comic books (unlike the original, which only had one comic book in two parts and was very short). Because of that, in this case you can observe the interaction between allies, enemies and tests from the moment Pavitr decides to be a hero. There are two elements that stand out: First, his main allies and enemies are a direct parallel to the original storyline (taking into consideration previous comic books and the 2002 cinematographic adaptation, in particular); thus, Pavitr is in love with Meera Jain (just like one of Peter's big loves was Mary Jane). Furthermore, the two great enemies in this storyline are Octopus (just like one of the original Spider-Man enemies) and Nalin Oberobi, who transforms into a green demon (just as Norman Osborne, who in the original storyline turns into the Green Goblin). The second element that stands out is the fact that both Octopus and Nalin Oberobi are rakashas, or mythological hindi demons (Kang et al., 2005b).

Shortly after the beginning of the fourth number in the series, there is an approach to the deepest cavern in almost a literal sense. Spider-Man finds out that Oberobi is in the refinery opening a portal to bring a horde of rakashas and when he approaches the place, it looks terrifying (Kang et al., 2005c).

In this storyline, the ordeal and reward go hand in hand. When Prabhakar is about to reach the place of the events, Oberobi-transformed into a fearsome rakasha_holds Meera Jaine and aunt Maya, who are hanging 
from their hands; he will let them fall to their death, hoping to deliver his own reward to Spider-Man:

That's right, boy. Time for you to make a decision. Time or your innocence to die. One will die... because of you! This is the gift I bring you, little spider — the gift of pain... and from pain —strength! (Kang et al., 2005c, p. 11-12)

Naturally, Pavitr tries to save both, but it is impossible. When everything seems to be lost, Prabhakar obtains a series of rewards. He is able to save his aunt and an enemy becomes his ally: It is Octopus, who saved Prabhakar's love (Kang et al., 2005c).

Finally, the road back, resurrection, and elixir come together in a climactic moment: Before returning to his normal life, or to his new life with powers, Pavitr must defeat Oberobi. However, this will not be simple-to do it, he must prove to himself that he has changed, for he faces a new and great challenge.

Oberobi wants Spider-Man to give in to the hate-that way he will be able to shift him to the rakasha's side and absorb his power: "Give in to the hate... let these dark thoughts consume you, little spider [...] Let the sweet kiss of the amulet envelop you. Do not fear it ... Embrace it!" (Kang et al., 2005c, pp. 22-23).

Oberobi's attempts lead to Pavitr being divided, but he remembers Bhim's teachings: "One day you'll have a chance to really help people and change this country. It's not hate that's going to get you there... with great talent, with great power... there must also come great responsibility" (Kang et al., 2005c, pp. 23-27).

Pavitr manages not to give in to the rage and that weakens this rakasha, which gives him time to take the amulet that Oberobi used to summon the demon and destroy it. It is at this moment that Spider-Man is resurrected, a new being, a complete hero who took the gift his uncle had given him and transformed it into his own elixir: He will be a hero that will not give 
in to rage, despite the damage they might have inflicted on him beforehand and the one he might receive in the future.

The end of the storyline is a complete closure, including Pavitr's celebration with his aunt Maya on Diwali (Hindi new years' celebration).

\section{The Hero's Journey of Takuya Yamashiro from Earth 51778}

On May 17, 1978, the first episode of another Spider-Man aired on television. In this case, it was the young Takuya's turn to change into the invincible Supaidaman.

The pre-call to adventure is also present in this storyline. In this case, the young man feels himself being summoned by Garia's telepathy and through the superposition of images the audience is made to understand that the shadow of a spider can be seen in his mind.

Despite being bothered by the telepathy, in his ordinary world Takuya keeps on with his life. In this occasion, this is not a timid schoolboy who gets picked on by his classmates. Unlike Peter and Pavitr, he is a very self-confident, motorcycling acrobat (Saeki \& Uehara, 1978).

Takuya's refusal occurs in later scenes, when he chooses not to get involved in the excavation of a meteorite that has fallen to Earth. This is also an unconscious rejection of his father-they both care greatly for each other, but Takuya prefers his motorcycle to supporting his father in his investigations (Saeki \& Uehara, 1978).

In this work, there are steps of the journey that also come together in a few scenes. Here, the approach to the deepest cavern, the meeting with the mentor, the ordeal, and the reward all happen together in relatively short moments.

Takuya cannot avoid the telepathic calls, which makes him look for their source. Along the way, he finds his agonizing father, who, before dying, reveals to him that there is group trying to invade Earth (Saeki \& Uehara, 1978). 
His father's death is the darkest moment of this episode and perhaps the whole series. This moment is followed by a fall into a literal cavern, when he is defeated by the Iron Cross Army (the group that wants to invade Earth). His defeat and fall are so abrupt that there is not enough time to prepare or approach (Saeki \& Uehara, 1978).

In the cave he meets Garia, the last survivor of the Spider planet, a world that was destroyed by the Iron Cross Army. Takuya is gravely injured and, to save him, Garia injects him with drops of the Spider Extract. These give him his power, the reward of Supaidaman (Saeki \& Uehara, 1978). From henceforth, Takuya will have superhuman strength, the skills of a spider, spider sense, and the faithful companionship of a spaceship called Marveler, which transforms into a giant robot known as Leopardon (Saeki \& Uehara, 1978).

Garia completes the teachings that Takuya's father began, becoming a sort of co-mentor. He explains that the group trying to secretly invade Earth is the same that destroyed his planet, the Iron Cross Army led by Professor Monster. He gives him the mission of defending Earth and, before ceasing to be a man and becoming a spider, he also asks him to take over his own mission to avenge his planet (Saeki \& Uehara, 1978).

From this point on, Supaidaman's enemies are the Iron Cross Army, Professor Monster, his faithful servant Amazona and the monsters she liberates in each episode. In this stage of the allies, enemies and tests is when the elements that draw the attention of this investigation appear. These elements are mainly three, which belong to the series genre-Tokatsu (all the Japanese shows that make excessive use of special effects): 1) in each episode, Supaidaman will have minor fights with a group of anonymous, low skilled fighters; 2) in each episode, Yamashiro will have to fight a monster that, after a few moments, will finally become a giant; and which 3) makes it necessary for Takuya to climb into his spaceship, Marveler, and transform it into a giant robot that, piloted by him, will destroy the monster (Saeki \& Uehara, 1978).

Going back to the first episode, the road back, the resurrection and the return with the elixir happen when Supaidaman faces the first monster 
in the series, Boukuryu (Saeki \& Uehara, 1978). Boukuryu will grow until it transforms into an enormous monster, but Spider-Man will defeat it piloting his own giant robot.

From this point on —and for the duration of 41 episodes-Takuya will be Supaidaman, the greatest enemy of the Iron Cross Army and Professor Monster.

\section{Spider-Verse as Retroactive Linkage}

The case of the Spider-Verse is a pretty recent effort (2014) that tried to unite all the existing Spider-Men, including one that dates 10 years back-the Indian Spider-Man (Kang et al., 2005) —and an even older one - the Japanese Supaidaman (Saeki \& Uehara, 1978). However, as has been previously mentioned, the journeys between universes and dimensions are not something new for Marvel (McMillan, 2014) or Lee and Richardson’s (1998) Spider-Man (more specifically, season five of Spider-Man the Animated Series).

In a nutshell, Spider-Man's travels across multiple dimensions are not something new to the audience, which makes this Retroactive Linkage easily integrated with the series. However, this is the first time where characters created in other cultures are integrated. It could be said that this series is the first to unite universes that were conceived in a totally separate manner.

For this investigation, coherence-a central element in a retroactive linkage (Wolf, 2012) —is presented from the basis of the rules that the fiction in itself establishes in all its publications. In the case of this series, the issues published for the Spider-Verse look to unify all the existing Spider-Men through the Web of Life and Destiny. Throughout the series, the different Spider-Men travel through multiple universes along this web, together with the character in charge of it-the Great Weaver-explains that the spider sense, understood as the capacity to feel future threats, is an element that unites all the Spider-Men with the web (Slott, et al., 2015).

In short, the sole possession of powers and the spider sense are important clues to identify a true Spider-Man. They have received their powers because 
of their destiny. Finally, another unifying element of every Spider-Man is the comprehension of the responsibility they are given through sacrifice. This is a key element to understand who is a real Spider-Man within this universe. Towards the end of the Spider-Verse series, this is explained in an explicit way when Superior Spider-Man (Otto Octavius in Peter Parker's body) wants to show the Spider-Man from Earth 616 that he is the greatest of all the heroes and Peter answers:

No contest, Otto. A real hero wouldn't have threatened Anya. Or risked the fate of the universe to save his own skin. The greatest heroes put others in front of themselves. One day you will understand that. On the day you sacrifice everything. (Slott et al., 2015, p.13)

\section{Conclusions}

The existence of a Marvel Multiverse since 1983 and of a Spider-Verse since at least 1998 integrates the 2014 experiment to the Spider-Man canon without difficulty, given that Peter Parker's travels across multiple universes and meeting different Spider-Men is something that has already been accepted by the audiences. This would be a retroactive linkage that has been done carefully enough as to not clash with previously established elements.

The rules established by this retroactive linkage, in which each Spider-Man must possess his spider sense and put others before himself-something they have learned after sacrificing everything — are thoroughly accomplished by Pavitr and Takuya, just as Peter did. Upon receiving their spider powers, all three characters receive the spider sense; besides, in each case the hero only understands his real responsibility once he has suffered the sacrifice of his most beloved person (in the North American and Indian versions this person is an uncle that has become a father figure, while in the Japanese version it is his actual father).

Seen as transfictional adaptations, movements of transposition, expansion and displacement can be seen in both Spider-Men. It is worth noting that, being integrated through Retroactive Linkage in a transmedia multiverse, they end up fulfilling one of the most important elements for Jenkins - the expansion of the known Spider-Man universe. It is also worth 
noting that, by taking stories to different cultural contexts, not only is transposition inevitable, but one also gets displacement movements relative to the original storyline. However, it is clear that the displacement is much less evident in the Indian version of Spider-Man. On the other hand, the Japanese television show's displacement is such that pretty much the only thing that remains is the superhero's name, suit and powers. Aside from that, all the other elements are from the Tokatsu series.

When breaking down the transduction process, we can see that, asides from changing the worlds, there are various elements that are introduced to re-culturalize Spider-Man and make him a part of the countries to which he is adapted. To the naked eye, the strong presence of religious elements in Indian Spider-Man stands out, such as fighting the rakasha demons, or the fact that Spider-Man wears a dhoti (traditional Indian pants), or that the series ends with the celebration of Diwali (a sort of Hindu new year celebration). In the case of the Japanese Supaidaman, the first thing that catches the eyes is that it is written following the rules of a typical Tokatsu Japanese show, complete with exaggerated use of special effects and, of course, the always present monsters and giant robots.

In this effort to strip down the transduction process, it is interesting to stop and analyze the moment when the three Spider-Men obtain their powers. In the North American case, this happens with a scientific accident associated to radiation, a tendency that continues in other American 60's comic books, like The Fantastic Four, Hulk, Negative Man and Dr. Manhattan, amongst others (Jordi \& Senabre, 2015); in the Indian case, it is marked by religiousness (something very typical of Hindi culture); and in the Japanese case, the powers come from an alien (something very in sync with the Tokatsu series from Japan).

Finally, in the Japanese series there is another element that adds to the others, separates it from the original comic book and makes it have more elements of Japanese culture. While in the Indian and North American versions there is a responsibility that stems from suffering, in the Japanese not only does this happen, but there is another motivation to his 
struggle: double vengeance, for his father's death and the destruction of Garia's planet. The stories of revenge are something pretty commonly present in Japanese culture and are linked to the idea of "honor above all" in Samurai legends. An example of this is the legend of the 47 Ronin, whose only purpose of existence is to avenge their master.

\section{References}

Campbell, J. (1949). The hero with a thousand faces. New York: Pantheon Books.

Christiansen, J. (2007). Omniverse: a glossary of terms. Retrieved from http://www.marvunapp.com/ohotmu/appendixes/omnapp.htm

Dena, C. (2009). Transmedia practice: Theorising the practice of expressing a fictional world across distinct media and environments (Doctoral dissertation, University of Sydney, Australia). Retrieved from https://dl.dropboxusercontent.com/u/30158/DENA_TransmediaPractice.pdf

Frago, M. (2005). Reflexiones sobre la adaptación cinematográfica desde una perspectiva iconológica. Comunicación y Sociedad, 18(2), 4982. Retrieved from http://www.unav.es/fcom/communication-society/es/articulo.php?art_id=71

García Canclini, N. (2000). Culturas hibridas: estrategias para entrar y salir de la modernidad. Bogotá. D.C.: Grijalbo.

Jenkins, H. (2003). Transmedia storytelling: Moving characters from books to films to video games can make them stronger and more compelling. MIT Technology Review. Retrieved from https://www.technologyreview.com/s/401760/transmedia-storytelling/

Jenkins, H. (2006). Convergence culture: Where old and new media collide. New York: New York University Press. 
Jenkins, H. (2009, December 12). The revenge of the origami unicorn: Seven principles of transmedia storytelling (well, two actually. Five more on Friday) [Blog Entry]. Retrieved from http://henryjenkins. org/2009/12/the_revenge_of_the_origami_uni.html

Jordi, X. \& Senabre,J. (2015). Superhéroes nacidos en la radiación. Retrieved from https://desayunoconfotones.org/2015/02/19/super-heroes-nacidos-radiacion/

Kang, J., Seetharaman, S. \& Devarajan, S. (2005a). Spider-Man India \#1. New York: Marvel Comics.

Kang, J., Seetharaman, S. \& Devarajan, S. (2005b). Spider-Man India \#2. New York: Marvel Comics.

Kang, J., Seetharaman, S. \& Devarajan, S. (2005c). Spider-Man India \#3. New York: Marvel Comics.

La Pastina, A. C. \& Straubhaar, J. D. (2005). Multiple proximities between television genres and audiences: The schism between telenovelas' global distribution and local consumption. International Communication Gazette, 67(3), 271-288. doi:10.1177/0016549205052231. Retrieved from https://www.researchgate.net/publication/258137488_Multiple_Proximities_betwen_Television Genres_and_Audiences_The_Schism_between_Telenovelas' Global_Distribution_and_Local_Consumption

Lee, S. (Producer) \& Richardson, B. (Director). (1998). Spider-Man the animated series, Season 5. California: New World Entertainment Films.

Lee, S. \& Ditko, S. (1962). Amazing Fantasy 15: Spider-Man. New York: Marvel Comics.

McMillan, G. (2014, November 15). Worlds collide: a history of Marvel and DC's multiverses. The Hollywood Reporter. Retrieved from http:// 
www.hollywoodreporter.com/heatvision/worlds-collide-a-history-marvel-748649

Moore, A., Davis, A., Craddock, S. \& Jayce, B. (1983). The Daredevils \#7. New York: Marvel Comics.

Raimi, S. (Director) \& Arad, A. (Producer). (2002). Spider-Man. Sony Pictures Entertainment: Los Angeles.

Ryan, M. (2008). Transfictionality across media. In P. John (Ed), Theorizing Narrativity (pp.385-418). Berlin and New York: Walter de Gruyter.

Saeki, T. (Director) \& Uehara, S. (Writter). (1978). Supaidaman: Fukushī no Toki wa Kitareri! Ute Tetsu Jüji Dan!! Japan: Toei Company.

Scolari, C. A. (2012). Narrativas transmediáticas en España: cuatro ficciones en busca de un destino cross-media. Communication \& Society, 25(1), 137-163. Retrieved from http://www.unav.es/fcom/ communication-society/es/articulo.php?art_id=409

Scolari, C. A. (2013). Narrativas transmedia: cuando todos los medios cuentan. Barcelona: Deusto.

Scolari, C. A. (2014). Don Quixote of La Mancha: Transmedia storytelling in the grey zone. International Journal of Communication, 8, 2382 2405. doi: 1932-8036/20140005. Retrieved from http://ijoc.org/ index.php/ijoc/article/view/2576/1199

Slott, D., Cumuncoli, G., Smith, C., Poggi, R. \& Ponsoir, J. (2015). The Amazing Spider Man \#15. New York: Marvel Comics.

Slott, D., Gage, C., Camuncoli, G., Dell, J. \& Fabela, A. (2014). The Superior Spider-Man \#32. New York: Marvel Comics.

Straubhaar, J. D. (1991). Beyond media imperialism: Asymmetrical interdependence and cultural proximity. Critical Studies in Mass Co- 
munication, 8(1), 39-59. Retrieved from http://www.academia. edu/168858/Beyond_Media_Imperialism_Asymmentrical_Inerdependence_and_Cultural_Proximity

Uribe-Jongbloed, E. \& Espinosa-Medina, H. (2014). A clearer picture: Towards a new framework for the study of cultural transduction in audiovisual market trades. OBSERVATORIO $\left(\mathrm{OBS}^{*}\right)$ 8(1), 2348. doi: 1646-5954/ERC123483/2014

Vogler, C. (1998). The writer's journey (2nd. Ed.). Studio City: Michael Wiese Productions.

Wang, G. \& Yue Yu Yeh, E. Y. (2005). Globalization and hybridization in cultural products: The cases of Mulan and Crouching Tiger, Hidden Dragon. International Journal of Cultural Studies, 8(2), 175193. doi: $10.1177 / 1367877905052416$

Wolf, M. (2012). Building imaginary worlds: The theory and history of subcreation. New York: Routledge. 